Научная статья

УДК 18

DOI: $10.18101 / 1994-0866-2020-4-49-53$

\title{
«СОБОРНЫЙ ТЕАТР» СЕРЕБРЯНОГО ВЕКА
}

\author{
(C) Битюцкая Алла Альбертовна \\ аспирант, \\ Воронежский государственный университет, \\ Россия, 394018, г. Воронеж, Университетская площадь, 1 \\ alla-bituzk@mail.ru
}

\begin{abstract}
Аннотация. В статье обоснован феномен «соборного театра» и «синтетического театра», повлиявший на развитие русской философии ХХ в. В ходе исследования выявляется следующее. Во-первых, категория «соборного театра» откроет новый вектор для русской философии, возведя театр в ранг метафизики. Соборный театр станет мистическим воплощением воззрений мыслителей Серебряного века. Вовторых, рассмотрена троичная структура театрального действия: катарсис, мимезис, система масок, которая будет заимствована интеллигенцией для перфомансов. Многие спектакли по данной системе будут созданы в ведущих столичных театрах. В-третьих, воззрения Вячеслава Иванова зададут основу теургии и эстетики Серебряного века. Созданный образ человека-теурга трансформирует представления общества о личности-творце, которой подвластные мировые творческие процессы. Подобные воззрения станут откроют новую эру в персоналистической этике.

Ключевые слова: соборный театр; Вячеслав Иванов; катарсис; мимезис; система масок; Серебряный век; русская философия; теургия.
\end{abstract}

\section{Для цитирования}

Битюцкая А. А. «Соборный театр» Серебряного века // Вестник Бурятского государственного университета. Философия. 2020. Вып. 4. С. 49-53.

Развитие философии творчества Серебряного века невозможно представить без театрального воплощения и идеи создания нового русского театра. Открытие Немировичем-Данченко в Москве в 1898 г. Художественного Общедоступного театра (впоследствии МХТ имени Чехова) провоцирует всплеск эстетических поисков и обновления драматической этики. Интеллигенция предпринимает попытки преобразования театральной игры. Если московская элита отдавала предпочтение сохранению русского театра, то санкт-петербургская стремилась создать реминисценцию античной и итало-испанской драматургии в рамках северного храма искусства. Главным зачинателем «театра будущего» стал Вячеслав Иванов.

Вячеслав Иванов - идеолог символизма, теоретик Серебряного века, восторженно воспринявший концепцию теургического знания и всеединства, смог апробировать е в лоне театральной эстетики. Перед собой мыслитель ставит задачу преобразования театрального действия, потому что «старая сцена почти уже не заражает и, главное, не преображает зрителя» [2, с. 76]. Воззрение получит название «соборный театр». 
Концепция «соборного тетра» наполнена оттенками софиологии: троичность, феминное доминирование, триада истины, красоты, добра - все наполняет обновленный театр. В основе заложена категория античной трагедии как аннигиляция ритуала.

Трагедия - это распад «вечно враждующих» энергий монады жреца и жертвы (маскулинное начало) и диады спутниц Диониса - менад (феминное начало). Поэтому предпочтительнее изображать трагедию с женском ликом, здесь видна отсылка к ипостаси Софии и её роли. Трагедия обретает непосредственную форму искусства, когда в нее проникает аполлонийское начало. Театр - храм Диониса, в котором на авансцене играет трагедия. Стоит сделать ремарку, что «трагедия» - это литургическое служение дионисийскому началу.

Структура соборного театра троична: катарсис, мимезис, система масок. Категории заимствуются из античной эстетики, а именно из воззрений Аристотеля. Вячеслав Иванов считает, что у греческого мыслителя однолинейный взгляд на проблему, потому что трагедия не может отождествляться только с одной эстетикой.

Катарическое действие - первая ступень - редуцирующее действие, освободительный элемент от олимпийской символики. Катарсис дарует зрителю единение со сценическим действием, словно слияние микро- и макрокосмоса. Мимезис - вторая ступень аристотелевской эстетики, транслирующая индивидуальное отражение личности зрителя. Впервые подражание демаркирует театр (общее) и зрителя (единичное) и получает название «театра-зеркала». Третья ступень - маски - отсылка к царству Аида и погребальным ритуалам, которые напоминают зрителю о фатуме. Иванов, в отличие от Аристотеля, будучи вдохновленным работой в Италии и посещением местных карнавалов, видит в масках лишь внешний код персонажа, подталкивающий сорвать преграду с лиц актеров и посмотреть в истинную сущность. Возможно, ценность масок обусловлена потенциальным воскресением Диониса, о котором упоминается в теургических статьях, где символы смерти вместе с катарсисом могут стать «...единственным путем и способом превращения людского сонма в художественное создание» $[2$, c. 202]. Три элемента сливаются в душе зрителя и на выходе объединяют театральную публику.

Высший смысл соборного театра - создание мистерии. Трагедия становится эрзацем мистерии. Иванов грезит созданием в русском театре подлинной мистерии как индивидуального психического архетипа. Мистерия проявляется в хоровом действии. Поэтому философ уделяет трепетное внимание театральном процессу.

Театральный процесс, так же как и трагедия, троичен: хор, герой, миметизм. Хор - элемент множественности, герой - акт индивидуального, миметизм сведение к неразделимому синтезу. Элементы воплощаются в соборности. Иванов стремится показать соборность в софиологическом ключе, поэтому театральная соборность - имманентный акт в трансцендентном драматическом космосе. Всеединство проявляется во взаимоотношениях героя и хора. Мыслитель на примерах из античной драматургии (хор в «Эдипе») иллюстрирует, что хор демонстрирует «всю мистерию» героя. Вячеслав Иванов считает, что именно из- 
за растворения многоголосия произошел упадок театра. Главный герой утратил свои стоические качества и стал лирическим. Зритель начинает довольствоваться «стенаниями Онегина, Ибсена и Дон Жуана», которые были немыслимы в древнем Эпидавре.

Чтобы более детально рассмотреть эстетизацию мира, философ презентует идею о четырех типах искусства: всенародное, демотическое, интимное, келейное. Каждый тип по-своему проявляется в жизни творца.

Театральная эра соответствует келейному типу как синтетическому искусству метафизического изволения (выход к мэону свободы). Келейность дарует необходимое спекулятивное таинство творцу и дает возможность функционировать архетипу актера, как очередного явления бога превращений, Диониса.

В новом мире творчества господствует художник. Художник как теург реализовывает в посюсторонний мир человека-артиста. Теург - как проектор транслирует идеи соборного знания народным личностям. Безусловно, ивановский теург служит царству эстетики и всецело подвержен ему:

«Но для искусства я рожден; оно

Природу побеждает, коль дано

Художнику воззвать прообраз вечный» [7, с. 21].

Соборный театр должен, по мнению мыслителя, стать святилищем теурга и перерасти в театр будущего. Театр - дом великолепного теурга, который умеет претворять мистерию жизнь.

С приходом новой власти Вячеслав Иванов в своем выступлении «Скрябин и дух революции» отмечает, что революция - увертюра тотальной мистерии («крестный путь соборности»), которая возродит театр, что, собственно, и произошло благодаря титанической работе московской и питерской интеллигенции в двадцатые - тридцатые годы двадцатого века.

Поразительно, что концепция «соборного театра» создавалась во «внебашенный» период. Иванов размышлял о деятельности творца-жреца в своих зарубежных путешествия и во время работы переводчиком. Зато гости Таврической вдохновляются интенциями и начинают создавать собственные постановки для святилища Диониса. По воспоминаниям современников, философ часто старался направлять театралов на истинный путь: «...Это произошло 19 апреля 1910 г. на квартире Вячеслава Иванова, где я в шутку поставил комедию Кальдерона "Поклонение кресту". Играли не профессиональные актеры, а поэты и писатели. В общем, обычные гости знаменитых на тот момент Ивановских «сред». Это был эксцентричный эксперимент, который игрался в манере старинного испанского театра с использованием масок комедии дель арте. <... Он долго пел дифирамбы, а в конце задал вопрос: "Каким театром вы хотели бы сейчас заниматься?", на что я без раздумий ответил, что хотел бы пробовать в манере итальянской комедии дель арте. Он предложил мне открыть свою студию, где я смогу попробовать все, что пожелаю» [6, с. 155]. Так в Российской империи появился «Дом интермедий», впоследствии «Санктъ-Петербургъ Опера», существующая по сей день. 
Соборный театр, словно живое знание, должен измениться в сердцах людей, а потом уже в обществе. Народ - носитель творящего искусства. Иванов и после революции говорит о творящем всенародном искусстве как варианте развития советской культуры. Народ создает театральное преображение действительности, театрализацию жизни с помощью «масок» и театральной игры, народ наделяется чертами теурга и несет эстетическую миссию. Философ подчеркивает, что задача художника-народа - создание духовного всеединого знания.

«...Между прочим Д. сказал, что строить новые театры, по образцу античных, так, чтобы места зрителей окружали значительную часть сцены и последняя уподоблялась бы таким образом древней орхестре. Все это навело меня на мечты о том будущем, которое все мы, сознательно и бессознательно, (особенно бессознательно) предуготовляли или творили. Это будущее будет религиознее современности. Оно будет знать трагедию. Современный театр отойдет в область архаизмов. Опять раздадутся трагические хоры...» [4, с. 293].

Безусловно, современники будут инкриминировать великому теургу различные упреки об утопии и спекулятивной веры автора в триаду красоты, добра и истины. Критики специально подчеркивали, что «соборный театр» противоречит келейному типа искусства. Вячеслав Иванов рьяно парировал своим оппонентам и отстоял свою концепцию, зафиксировав постулаты «соборного театра» в своих статьях.

Таким образом, концепция Вячеслава Иванова перевернула представления о русском театре и его роли в искусстве. Гипертекстуальность театра, элементы боговдохновенности и образ пневматического гностического человека-теурга стали характерными чертами театральной эстетики. Благодаря данным воззрениям начинают появляться актерские студии и театры, посвященные синтетическим идеям. Спектакли, созданные по канонам триад, вызывают ажиотаж в российском обществе.

Например, постановка «Мелкий Бес», впервые показанная в Киевском театре в 1909 г., до сих пор идет на театральных подмостках. «Соборный театр» интерферирует с кружками художников («Мир искусства») и писателей, даровав обществу идею о создании театра. Идея будет реализована в Санкт-Петербурге: в 1912 г. был создан Театр Литературно-художественного общества им. А. С. Суворина. Сейчас театр называется Большой драматический театр имени Г. А. Товстоногова.

Русская театрократия поистине стала катализатором театрализации отечественной жизни. Такие имена, как Мейерхольд, Ермолова, Таиров, Комиссаржевская, станут легендами, а театры, созданные ими, - визитными карточками двух столиц.

Литература

1. Иванов В. И. Родное и вселенское. М.: Республика. 1994. 428 с.

2. Иванов В. И. Собрание сочинений: [в 4 т.]. Брюссель: [Foyer Oriental Chrétien], 1971-1987. T. 2. 1974. 852 c.

3. Иванов Вячеслав, Зиновьева-Аннибал Лидия. Переписка: 1894-1903. М.: Новое литературное обозрение, 2009. Т. 1. 752 с. 
4. Иванов Вячеслав, Зиновьева-Аннибал Лидия. Переписка: 1894-1903. М.: Новое литературное обозрение, 2009. Т. 2. 568 с.

5. Ивнев Р. Серебряный век: невыдуманные истории. М.: Э, 2017. 320 с.

6. Кемпо С. Мейер: [роман]. М., 2019. 352 с.

7. Микеланджело. Сонеты / пер. В. Иванова. СПб.: Изд-во Тимофея Макова, 2016. $30 \mathrm{c}$.

8. Одоевцева И. На берегах Невы. СПб.: Лениздат, Команда А, 2014. 480 с.

9. Одоевцева И. На берегах Сены. СПб.: Лениздат, Команда А, 2012. 480 с.

10. Розанов В. Уединенное. М.: БММ, 2013. 191 с.

11. Серебряный век русской журналистики. СПб.: Азбука, Азбука-Аттикус, 2012. $320 \mathrm{c}$.

12. Соловьев В. С. Мчи меня, память: стихотворения. М.: НексМедиа; М.: Комсомольская правда, 2013. 238 с.

13. Соловьев В. Смысл любви: избранные произведения. СПб.: Азбука, АзбукаАттикус, 2016. 352 c.

Статья поступила в редакичию 09.11.2020; одобрена после рецензирования 16.11.2020; принята к публикации 25.11.2020.

\title{
"COMMUNION THEATER" OF THE SILVER AGE
}

\author{
Alla A. Bityutskaya \\ Research Assistant, \\ Voronezh State University, \\ 1 Universitetskaya Square, Voronezh 394018, Russia \\ alla-bituzk@mail.ru
}

Abstract. The article substantiates the phenomena of "communion theater" and "total theater", which influenced the development of Russian philosophy of the $20^{\text {th }}$ century. The research has revealed that the category of "communion theater" would open a new vector for Russian philosophy, elevating theater to the rank of metaphysics. The communion theater will become the mystical embodiment of the views of the Silver Age thinkers. We considered the threefold structure of theatrical action: catharsis, mimesis, and a system of masks, which the intelligentsia will borrow for performances. Many performances under this system will be staged in the leading theaters of the capital. And the views of Vyacheslav Ivanov will set the foundation for theurgy and aesthetics of the Silver Age. The created figure of theurgist transforms society's ideas about the creator, who has power over the world's creative processes. Such views will open a new era in personalistic ethics.

Keywords: communion theater; Vyacheslav Ivanov; catharsis; mimesis; the system of masks; the Silver Age; Russian philosophy; theurgy. 